\title{
VALIDITY OF THE STANDARD SHIFTWORK INDEX FOR SOUTH AFRICAN SHIFTWORKERS IN THE TRANSPORT INDUSTRY
}

\author{
D. VISSER
}

Department of Human Resource Management

Rand Afrikaans University

\begin{abstract}
A major problem in shiftwork research has been the lack of uniform measuring procedures across studies. The Standard Shiftwork Index (SSI) contains a battery of self-report questionnaires which was developed to address this need. The objectives of this study included examining the cross- cultural applicability, intemal consistency, and construct validity of the SSI scales for a predominantly Afrikaans-speaking sample of 728 train drivers and to provide normative distribution statistics for this sample. Factor analytic results and the correlations between the various scales supported the constnuct validity of the SSI scales. Means obtained on the scales were compared with means obtained for British shiftworkers and non-shiftworkers. The inclusion of job satisfaction and involvement scales, and scales to assess sleep variables appeared to augment an outcome- based theoretical model proposed by the compilers of the SSI. It was concluded that the SSI is a useful research tool for use with shiftworkers, but that further development of some of the scales is advisable.
\end{abstract}

\section{OPSOMMING}

'n Belangrike leemte in navorsing oor skofwerk is die gebrek aan eenvormige metingsprosedures. Die Standard Shiftwork Index (SSI) behels verskeie selfbeoordelingvraelyste wat in Engeland ontwikkel is om hierdie behoefte aan te spreek. Die doelwitte van hierdie studie was om die tussenkulturele toepaslikheid, interne konsekwentheid en konstrukgeldigheid van die SSI-skale vir 'n hoofsaaklik Afrikaanssprekende steekproef van 728 treindrywers te bepaal en om normatiewe statistiek vir hierdie steekproef te verskaf. Faktoranalitiese resultate en die korrelasies tussen die onderskeie skale het hul konstrukgeldigheid ondersteun. Gemiddeldes wat op die onderskeie vraelyste behaal is, is vergelyk met gemiddeldes wat vir Britse skofwerkers en nieskofwerkers verkry is. Die insluiting van werktevredenheid- en werkbetrokkenheidskale, asook skale oor slaap, het die uitkomsgebaseerde teoretiese model van die opstellers van die SSI aangevul. Die SSI kan beskou word as ' $n$ nuttige navorsingshulpmiddel vir gebruik met skofwerkers, maar verdere ontwikkeling van sommige van die skale is gewens.

It is estimated that roughly 30 percent of the work force in most countries consists of shiftworkers (Klein, 1995) and that this percentage may be expected to increase as the economic necessity of increasing and optimising production time and providing services becomes more pressing. It is therefore surprising that research on the effects of shiftwork was relatively scarce until the past two decades and that this emerging discipline appears to lack specialised scientific journals catering exclusively for shiftwork research. Every second year an international symposium on aspects of shiftwork is organised by the Scientific Committee on Night and Shiftwork of the International Commission on Occupational Health, a multidisciplinary organisation that also publishes a international newsletter. As a result of the growing interest in the special circumstances of shiftworkers, the International Ergonomics Association also arranges a special shiftwork session at its triennial congress and the European Society for Chronobiology includes research papers on circadian rhythm during its annual meetings. However, shiftwork researchers have to submit their manuscripts to ergonomics and occupational health journals, because there is not yet an international journal for shiftwork research only.

In South Africa an exceptionally large proportion of workers (approximately 30\%) are involved in the service, mining, steel, petrochemical, and manufacturing industries, with the result that the South African economy also relies heavily on the contribution of its shiftworkers. Any work schedule that falls outside the day working window, taken as the hours between 07 h00 and 18h00, is commonly labelled as shiftwork (Monk \& Folkard, 1992). Shiftwork generally requires some adjustment, and in many cases an extreme lifestyle adaptation, on the part of workers because of their special work circumstances. Unless

Requests for reprints should be addressed to D Visser, Department of Human Resource Management, Rand Afrikaans University, P O Box 524, Auckland Park 2006 unusual working hours are approached scientifically, negative consequences for the worker may result. In spite of this, it appears that shiftwork research in South Africa has been largely neglected, because to date only a few South African studies in this field have been reported in the research literature (Adler, 1991; Brophy, 1993; Goldman. 1992; Pieterse, 1997; Potgieter, 1996; Shaw, 1980). It is the purpose of this study to establish which measuring instruments in the form of self-report questionnaires are suitable for use by local shiftwork researchers.

In the recent past the effects of shiftwork on the biological, physical, psychological, and social experiences of individuals have been researched extensively. It is a well- documented fact that shiftworkers experience unique problems not shared by day workers (Monk \& Folkard, 1992) and that some of the stresses experienced by day workers are intensified in the case of shiftworkers. These include

- Neuro-hormone imbalances affecting the circadian rhythm and sleep patterns. It is estimated that chronic sleep problems affect $60 \%$ to $80 \%$ of all shiftworkers (Klein,1995). Sleepiness and fatigue as a result of sleep deprivation, and also sleep disorders, such as obstructive sleep apnea and insomnia, appear to be common among shiftworkers (Bohle, 1997; Dumont, Montplaisir, \& InfanteRivard, 1997; Folkard \& Barton, 1993; Gallo \& Eastman, 1993; Harma, Kervinen, Sallinen, Lundelin, \& Toppila, 1997; Hildebrandt, Rohmert \& Rutenfranz, 1974; Lauber \& Kayten, 1988; Monk, 1990; Torsvall, Ảkerstedt, \& Gillberg, 1987; Visser, 1996). Despite the type of task or the kind of shiftwork, maximum sleepiness is experienced in the early hours of the morning (Kecklund, Akerstedt, Gillberg \& Lowden, 1997).

- Physical and general health problems such as chronic fatigue, digestive, cardiovascular, and other health pro- 
blems. An often-used slogan regarding shiftwork reads: 'Shiftwork is probably bad for the heart, almost certainly bad for the head, and definitely bad for the gut (Monk \& Folkard, 1992). Most shiftworkers tend to worry about the long-term consequences of their shiftworking routine, but health consequences are more likely to arise in individuals who are failing to cope with shiftwork (Smith, Robie, Folkard, Barton, Macdonald, Smith, Spelten, Totterdell \& Costa, 1997; Taylor, Folkard \& Shapiro, 1997). Until recently there was some uncertainty about a definite relation between shiftwork and cardiovascular disease, but current evidence appears to support such a relation (Knutsson, Hallqvist, Reuterwall \& Theorell, 1997; Tenkamen, Sjöblom, Kalimo, Alikoski \& Härmä, 1997) The extent of digestive problems are widely acknowledged, because most shiftworkers suffer some degree of digestive disorder ranging from peptic ulcers to mild indigestion (Heslegrave \& Rhodes, 1997). A common conclusion is that these digestive problems are caused to a large extent by a misaligned circadian system in the shiftworker (Prunier, Gadbois \& Foret, 1997).

- Problems relating to psychological well-being such as depression and anxiety. The link between shiftwork, psychological health, and neurotic behaviour is well established, with mood swings and depression being five to 15 times more likely to occur in shiftworkers than in day workers (Heslegrave \& Rhodes, 1997; Klein, 1995). In a recent study exploring the relation between exposure to shiftwork and the prevalence of major depressive disorder (MDD) Scott, Monk, and Brink (1997) found an unexpectedly high prevalence of MDD.

- Domestic and social problems manifested by high divorce rates, impaired social life disturbed relationships, and harmful substance abuse. Shiftwork significantly increases the odds of marriages ending in separation of divorce, with divorce rates for shiftworkers being $20 \%-60 \%$ higher than for day workers (Klein, 1995; Presser, 1997). In a study by Pisarski (1997), it was shown that support for the shiftworker by supervisors and family members is associated with increased psychological health and that this support acts as a moderator of the effect of work/nonwork conflict on health. Drug and/or alcohol abuse has been shown to be relatively common among shiftworkers, because many use these substances in an effort to overcome sleep problems (Buysse, 1991).

- Work performance problems, such as inefficiency due to fatigue, and lack of vigilance. In a classic shiftwork study, Hildebrandt et al. (1974) showed the consequences of lapses in vigilance which peaked during the night/early morning shift. These results support the influence of the circadian rhythm and the effects of increased sleepiness when the shiftworker is at his/her most vulnerable. The risk of accidents increases exponentially beyond eight hours on the job, and the exponential increase is more marked the later the start of the shift (Hänecke, Tiedeman, Nachreiner \& Grzech-Sukalo, 1997).

- Lessened job satisfaction and job involvement. Not much research has been done in this area, but shiftworkers often quote several reasons why they prefer shiftwork in spite of the health risks inherent in working unusual or irregular hours. Among these are financial benefits and greater freedom to spend day hours with the family. Yet the unique problems and stresses of shiftwork are hypothesised to affect extrinsic job satisfaction negatively. Barton, Costa, Smith, Spelten, Totterdell and Folkard (1995) found a positively skewed distribution on a measure of job satisfaction, indicating that the majority of the shiftworkers in their sample tended to rate their job satisfaction as relatively low. In a study among hospital doctors in India,
Sharmin and Rahman (1997) concluded that their job satisfaction depended on both the nature of the work (emergency, general, or both) and the work schedule (day work, rotating shifts, or both).

There are several difficulties in studying shiftwork, because many of the most important variables are difficult to measure or can be observed outside the workplace only, such as the sleep quality of shiftworkers. Furthermore, shiftwork research requires a multidisciplinary approach. Three approaches are generally used, namely field and survey studies and laboratory simulations. Due to their cost, field studies are relatively rare, but provide invaluable information. Typical studies may involve on-the-job performance measures, sleep diary measures, or body temperature measurements which is the way by which the status of the human circadian system is evaluated. Urine and/or blood samples may also be used for measuring hormonal levels that are associated with the circadian system.

In survey research questionnaires are generally used which implies that circadian rhythm or sleep diary measures cannot be obtained. This kind of research is subject to contamination by response bias and the Hawthorne effect, with the result that variables measured in this way are referred to as 'subjective' measures in the shiftwork literature. On the other hand, survey research is cheaper, easier to carry out, and larger samples may be studied. When the research problem deals with the perceptions of shiftworkers, or when the effect of interventions have to be assessed from the viewpoint of the worker, survey studies are called for.

A major problem in shiftwork research has been the lack of uniform survey measuring procedures across studies. The Standard Shiftwork Index (SSI) was developed recently by Barton, Costa et al. (1995) to address this need (see also Barton, Folkard, Smith, Spelten \& Totterdell,1995). It is a battery of selfreport questionnaires which focus on the health and psychological well-being of shiftworkers. Prior to the development of the SSI, several studies were published in which the perceptions and attitudes of shiftworkers were assessed by means of questionnaires (Barton \& Folkard, 1993; Iskra-Golec, 1993; Kaliterna, Vidacek, Radosevic-Vidacek \& Prizmic, 1993; Smith Brown, Di Milia \& Wragg, 1993). However, the SSI represents the first attempt to construct a comprehensive battery of relatively short questionnaires according to a theoretical outcome-based model of shiftwork behaviour (Barton, Costa et al., 1995), and which takes into account the growing research literature about the various problems experienced by shiftworkers.

The lack of standardised measures in shiftwork research has complicated the possibility of meaningful comparisons across different types of shiftworkers in terms of the problems typical of each type of shiftwork. If the same measuring instruments could be used with comparable groups of shiftworkers, it would facilitate decisions regarding the improvement of shift systems. Therefore, the SSI was developed as a standard instrument to assess the impact of different types of shift systems on shiftworkers. Barton Costa et al. (1995) suggested that these questionnaires should be used by other researchers to extend the available scale norms for comparisons across shiftworking groups and that the psychometric properties and suitability of the SSI in other languages and cultures should be investigated.

In published studies the SSI or selected scales thereof have to date been used with English samples mainly (Barton, 1994; Barton, Smith, Totterdell, Spelten \& Folkard, 1993: Scott et al., 1997; Spelten, Barton \& Folkard,1993; Taylor et al., 1997; Tucker, Smith Macdonald \& Folkard, 1997). An exception has been the application of the Coping Style Questionnaire which was recently used in South Africa with shiftworkers in the rubber industry (Potgieter,1996). Although the means, standard deviations, and often also the internal consistency reliability of 
the SSI scales, were reported for these studies, no systematic attempt has been made to examine the psychometric properties of the SSI for samples other than those used in the initial study by Barton, Costa et al. (1995). Neither have comparisons of results across different studies been made in order to compare the effects of different kinds of shifts.

The objectives of the present study were therefore to examine the internal consistency and, in particular, the construct validity of the SSI scales for a predominantly non-English-speaking sample of shiftworkers in South Africa, and to provide normative distribution statistics for this sample. Scales which appeared psychometrically unsound, especially in terms of content validity, were omitted or replaced in this study. Care was taken to include scales to address the wide range of problem areas discussed earlier which may affect shiftworkers. Therefore questionnaires relating to daytime sleepiness and sleep disorders were included to expand the scope of the SSI. Lastly, the scale means obtained by the South African sample were compared with means obtained in published studies using the SSI to provide yet another means of establishing the utility of the SSI for shiftwork research across cultures.

\section{METHOD}

\section{Participants and Procedure}

The target population consisted of all the train drivers, urban and long-distance, employed by a railroad company in South Africa. A pilot study involving 20 drivers was conducted to ensure that the content of the questionnaire was understood properly. In the main study, special care was taken to hand a questionnaire to each train driver employed by the company. They were requested to complete the questionnaires anonymously, to place them in addressed prepaid envelopes and to mail them to the researcher. Only 22 percent $(\mathrm{N}=728)$ of the drivers responded, but they represented the ten geographical regions and the urban/distance train services in the appropriate proportions. All of the participants were males of whom 91 percent indicated that they were Afrikaans-speaking. There were no female train drivers at the time of the study. Their ages varied between 20 and 56 years $(M=40, S D=6,59)$ and 95 percent indicated that they were married or living with a partner. On average they had been train drivers for 14,3 years $(\mathrm{SD}=6,11)$. More than 80 percent of the train drivers worked on highly irregular shift systems in which shifts longer than eight hours were common. It is believed that the length of the questionnaire contributed to the low response rate, but no evidence of bias in the sample could be detected from the biographical information obtained.

\section{Measuring instruments}

Following recommendations by Barton, Costa et al. (1995) that researchers might use some or all of the SSI scales depending on their specific requirements, all the scales of the SSI, with the exception of the General Job Satisfaction, Chronic Fatigue and Composite Morningness Questionnaires, were included in the questionnaire used in the present study. In the case of the Sleep Disturbance and Coping Strategies Questionnaires, fewer items were used to suit the requirements of the study. The job satisfaction and fatigue scales were dropped, because both are very short, and the items within each scale are too similar to claim adequate content sampling of the domain in question. The latter fact probably explains the satisfactory internal consistency coefficients that were obtained by Barton, Costa et al. (1995). The job satisfaction scale was replaced by two widely used scales, the Minnesota Satisfaction Questionnaire (Cook, Hepworth, Wall \& Warr, 1981; Weiss, Dawis, England \& Lofquist, 1967) and the Job Alienation/lnvolvement Questionnaire (Lefkowitz, Somers \& Weinberg, 1984; Roodt, 1991). The scales that were included reflect the most pertinent issues in current shiftwork research, namely the social and domestic lives of shiftworkers, sleep disturbance and fatigue, physical and mental health, coping strategies, personality type including circadian type and extraversion/introversion, and job satisfaction.

Another very important issue in shiftwork research which has direct occupational safety implications and which has been shown to be related to shiftwork, is the presence of daytime sleepiness and sleep disorders (Aguirre, Heitmann, Trutschel, Fordham Mathews, Khuri, Gerber \& Moore-Ede, 1997). A shortcoming of the SSI is that this aspect is neglected in the SSI, but it was given prominence in the present study by adding the Epworth Sleepiness Scale (Johns, 1991, 1992, 1994) and the Sleep Apnea Scale (Visser, 1996) to assess the extent to which shiftworkers suffer from symptoms of excessive daytime sleepiness, obstructive sleep apnea, and chronic limb movement disorder. The performance of shiftworkers who supply essential services, such as medical care, who have to operate machinery, or who have to drive, is at stake if they have impaired sleep due to sleep disorders.

The questionnaire was translated into Afrikaans by the author so that the indicated language preference (English or Afrikaans) of the participants could be met. In addition to the scales mentioned above, questions on a wide range of other aspects relating to the work of train drivers, including ergonomic factors, were included in the questionnaire, but will not be commented on in this report.

\section{RESULTS}

The computer package Statistical Analysis System (SAS) was used for the analysis of the data. The means and standard deviations of the scales were calculated to be available as normative data in future comparison studies. These results are reported in Table 1. For each of the SSI scales an attempt was made to replicate the factor structure that was obtained during the original scale construction (Barton, Costa et al., 1995) It was decided to follow an exploratory rather than a confirmatory approach which would allow for possible improvement of SSI scales by making suggestions, where necessary, for omitting or swopping items. The correlations between the various scales were subsequently studied as a further attempt at construct validation. Internal consistency reliabilities were computed and compared with reliabilities found during the scale construction. Finally, the means obtained by the train drivers on the various scales were compared with means obtained in other studies where these scales have been used.

The following procedure was carried out to investigate the dimensionality of each scale separately. An iterated principal factor analysis was carried out on the items of each scale. The eigenvalues of the intercorrelation matrix of the items and results of the scree test were studied in order to decide on the appropriate number of factors to be extracted. To maximise interpretableness, the factor analysis was followed by oblique rotation using the Promax procedure. For every scale the factor loadings in the rotated factor pattern matrices (standardised regression coefficients) were interpreted to determine the dimensionality of the scales.

The results of these factor analyses are now briefly discussed. Due to the number of analyses performed, it was not possible to include tables of the factor matrices in the results section.

\section{Sleep Disturbance Questionnaire}

Five of the six items measuring quality of sleep before morning, afternoon, or night shift, or before days off, were used in the present study. The wording of the items was changed from 'between successive (morning) shifts' to 'before (morning) shifts', because most of the train drivers worked irregular shifts. The item 'do you feel tired on (morning) shifts' was dropped, because it deals with fatigue, whereas the other items deal 
directly with sleep patterns. The twenty items produced a fivefactor solution with the items for each shift clustering together, except for the four 'difficult to sleep' items forming a separate factor. The latter finding was replicated when four factors were extracted. Interfactor correlations varied from 0.18 to 0.55 .

\section{Physical Health Questionnaire}

The original 18-item questionnaire produced a clear three-factor structure. Two factors were associated with cardiovascular and digestive symptoms, whereas the third was defined by items $m$, $\mathrm{n}, \mathrm{p}$, and $\mathrm{r}$, and was named a weight factor. A two-factor solution was subsequently specified as indicated by the scree test, whereupon the items loaded on the appropriate subscales. The two items ( $p$ and $r$ ) that were dropped during the construction of the SSI due to their low factor loadings (Barton, Costa et al., 1995) also had the weakest factor loadings in the present study. A re-analysis of the 16-item questionnaire produced distinct cardiovascular and digestive factors $(r=0.53)$.

\section{General (Mental) Health Questionnaire}

The scree test indicated a one-factor solution that was named a factor of general psychological well-being.

\section{Cognitive-Somatic Anxiety Questionnaire}

The scree test clearly suggested a one-factor solution. Two highly correlated factors $(r=0.61)$ were nevertheless extracted following the eigenvalue larger-than-one criterion. Four Items (i, $\mathrm{j}, \mathrm{k}, \mathrm{n})$ had substantial loadings $(>0.3)$ on both factors, and all items except Item c had their highest loadings according to expectation on the cognitive and somatic anxiety subscales. Item $f$ ('I get diarrhoea') did not load substantially on either of the factors.

\section{Coping with Shiftwork Questionnaire (Private Life)}

The four general problem areas covered in the coping questionnaire of the SSI were reduced to one area only, namely private life, resulting in four items each for engagement (approach) and disengagement (avoidance) coping strategies. During the pilot study several train drivers indicated that they had difficulty in relating the various strategies to each problem area specifically. The term 'private life' was used in an effort to find an umbrella term for the social, domestic, and sleep areas. The scree test and eigenvalue larger-than-one criterion indicated a two-factor solution in which all items loaded substantially on the appropriate subscales with a correlation of 0.33 between the factors.

\section{Circadian Type Inventory}

A two-factor solution was specified for both the 30-item and 18 -item versions of the inventory. When the 30 items were

TABLE 1

PSYCHOMETRIC INFORMATION REGARDING THE SCALES USED IN THE STUDY

\begin{tabular}{|c|c|c|c|c|c|}
\hline Scale & $\mathrm{M}$ & SD & No. of items & $\mathrm{N}$ & Alpha coefficient ${ }^{*}$ \\
\hline Social Disruption & 3.81 & 1.26 & 1 & 727 & \\
\hline Domestic Disruption & 3.41 & 1.27 & 1 & 726 & \\
\hline Nondomestic Disruption & 3.21 & 1.30 & 1 & 723 & \\
\hline \multicolumn{6}{|l|}{ Sleep disturbances before: } \\
\hline Morning Shifts ${ }^{* *}$ & 13.02 & 3.78 & $5-6$ & 723 & $0.66(0.83)$ \\
\hline Afternoon Shifts ${ }^{* *}$ & 14.98 & 4.62 & $5-6$ & 716 & $0.77(0.79)$ \\
\hline Night Shifts ${ }^{* *}$ & 16.82 & 5.24 & $5-6$ & 716 & $0.83(0.83)$ \\
\hline Days Off** & 13.52 & 4.13 & $5-6$ & 713 & $0.70(0.76)$ \\
\hline Sleep Apnea Scale & 23.47 & 6.48 & 12 & 722 & 0.83 \\
\hline Epworth Sleepiness Scale & 7.54 & 3.89 & 8 & 722 & $0.75[0.88,0.73]$ \\
\hline Physical Health: Digestive & 14.23 & 5.07 & 8 & 724 & $0.88(0.86)$ \\
\hline Physical Health: Cardiovascular & 10.16 & 2.96 & 8 & 722 & $0.80(0.76)$ \\
\hline General Mental Health & 10.94 & 5.89 & 12 & 718 & $0.89(0.88)$ \\
\hline Cognitive Anxiety & 12.56 & 5.66 & 7 & 720 & $0.84(0.86)$ \\
\hline Somatic Anxiety & 14.04 & 5.29 & 7 & 720 & $0.81(0.80)$ \\
\hline Coping: Engagement ${ }^{* *}$ & 50.32 & 15.16 & $4-16$ & 700 & $0.70(0.85)$ \\
\hline Coping: Disengagement ${ }^{* *}$ & 38.56 & 15.44 & $4-16$ & 695 & $0.70(0.90)$ \\
\hline \multicolumn{6}{|l|}{ Circadian type: } \\
\hline Languidness/Vigorousness & 38.16 & 8.67 & 15 & 723 & 0.79 \\
\hline Flexibility/Rigidity & 48.38 & 7.70 & 15 & 723 & 0.73 \\
\hline Languidness/Vigorous - Final & 25.80 & 6.67 & 10 & 723 & $0.78(0.73)$ \\
\hline Flexibility/Rigidity - Final & 27.10 & 5.42 & 8 & 723 & $0.75(0.79)$ \\
\hline Neuroticism & 11.24 & 3.19 & 6 & 720 & $0.66(0.73)$ \\
\hline Extraversion & 15.62 & 3.33 & 6 & 721 & $0.63(0.75)$ \\
\hline Minnesota Satisfaction & 66.16 & 11.54 & 20 & 722 & $0.87[0.80+]$ \\
\hline Alienation/Involvement & 52.89 & 9.24 & 15 & 718 & $0.82[0.85]$ \\
\hline
\end{tabular}

* The coefficients in round brackets were obtained by Barton, Costa et al. (1995) for a sample of 332 industrial and service shiftworkers during the development of the SSI, whereas the coefficients in square brackets were obtained in other local or international studies (Johns, 1992; Roodt, 1991; Weiss et al., 1967).

${ }^{* *}$ In these instances fewer items per scale were used than in the original SSI scales (Barton, Costa et a., 1995). Statistics were adjusted accordingly. 
factor-analysed, ten items loaded above 0.30 on the languidness in overcoming drowsiness factor, including four items which were initially regarded as flexibility of sleeping habits items by Barton, Costa et al. (1995). Twelve Items loaded on the flexibility of sleeping habits factor. In the final 18-item version eight items defined the flexibility factor which correlated -0.32 with the languidness factor on which ten items loaded, duplicating the results of Barton, Costa et al. (1995). All factor loadings were larger than 0.30 . Results for both versions of the inventory are provided in the tables.

\section{Eysenck Personality Inventory}

In a two-factor solution $(\mathrm{r}=-0.26)$, the items loaded on the appropriate subscales of neuroticlsm and extra version, but item $\mathrm{g}$ on the extraversion scale had a factor loading of 0.14 , resulting in only five appropriate items for extraversion.

For each scale and/or subscale an index of the homogeneity of items was computed by means of Cronbach's alpha coefficient. The results of these and other psychometric properties of the scales are reported in Table 1 . The alpha coefficients varied between 0.63 (Extraversion) and 0.89 (General Mental Health). Reliability coefficients obtained by Barton, Costa et al. (1995) are provided in round brackets, whereas coefficients provided in square brackets were obtained in other local or international studies (Johns, 1992; Roodt, 1991; Weiss et al., 1967).

The intercorrelations among all the scales were studied, but the matrix is too large to report here. Substantial correlations (mostly >0.35) were obtained between the sleep-related variables, particularly sleep disturbances before night shifts, sleep apnea, and circadian type, and the various physical and mental health variables. The correlations between the moderator and outcome variables of the model proposed by Barton, Costa et al. (1995) are presented in Table 2. Extraversion and the engagement coping strategy were generally unrelated to the outcome variables. The disengagement strategy was positively correlated with several outcome variables, the lowest correlation with the psychological health variables being 0.34 . Inability to overcome drowsiness (languidness) and rigidity of sleeping habits were correlated in the expected direction with every outcome variable, including job satisfaction and involvement. Languidness in particular had consistently higher correlations than other moderator variables with the outcome variables relating to physical and psychological health and sleep difficulties. The use of a stringent alpha level was necessitated by the large sample sizes and to protect against inflated Type I error levels. When viewing the correlations as effect sizes (Rosenthal \& Rosnow, 1991), the asterisks in Table 2 have a different meaning, because they draw attention to the larger effect sizes.

Means obtained on the various questionnaires were compared with means obtained in other studies (Barton, 1994; Barton, Costa et al., 1995; Barton et al., 1993; Johns, 1991; Potgieter, 1996; Roodt, 1991; Spelten et al., 1993; Weiss et al., 1967) using $t$ tests for independent groups. In order to gain insight into the 'practical importance' of the obtained differences, Pearson $r$ effect sizes were calculated (Rosenthal \& Rosnow, 1991) The calculations were done by hand and the results are presented in Tables 3 and 4 . Significant $t$ values at the 0.01 level are indicated by asterisks.

\section{DISCUSSION}

It is concluded that the SSI is suitable for use as a research tool with the population of predominantly Afrikaans-speaking train drivers in South Africa. In general, the results were remarkably similar to the results obtained during the development of the SSI. The recommendation by Barton, Costa et al. (1995), namely that research should be undertaken to investigate whether the

TABLE 2

\section{CORRELATIONS BETWEEN MODERATOR AND OUTCOME VARIABLES}

\begin{tabular}{|c|c|c|c|c|c|c|c|}
\hline \multirow[b]{3}{*}{ Outcome variables } & \multirow[b]{3}{*}{ Extraversion } & \multicolumn{5}{|c|}{ Moderator variables } & \multirow[b]{3}{*}{$\begin{array}{c}\text { Flexibility } \\
\text {-Final }\end{array}$} \\
\hline & & \multicolumn{3}{|c|}{ Coping Strategy } & \multicolumn{2}{|r|}{ Circadian Type } & \\
\hline & & Engagement & $\begin{array}{c}\text { Dis- } \\
\text { engagement }\end{array}$ & Languidness & Flexibility & $\begin{array}{l}\text { Languidness } \\
\text { - Final }\end{array}$ & \\
\hline Social Disruption & -0.01 & 0.10 & $0.15^{*}$ & $0.30^{*}$ & $-0.20^{*}$ & $0.29^{*}$ & $-0.25^{*}$ \\
\hline Domestic Disruption & -0.03 & 0.07 & $0.16^{*}$ & $0.27^{*}$ & $-0.21^{*}$ & 0.25 & $-0.24^{*}$ \\
\hline Nondomestic Disruption & -0.09 & 0.03 & 0.07 & $0.18^{*}$ & $-0.23^{*}$ & $0.17^{*}$ & $-0.22^{*}$ \\
\hline \multicolumn{8}{|l|}{ Sleep disturbances before: } \\
\hline Morning Shifts & -0.11 & 0.01 & $0.20^{*}$ & $0.32^{*}$ & $-0,29^{*}$ & $0.31^{*}$ & $-0.21^{*}$ \\
\hline Afternoon Shifts & -0.08 & 0.11 & $0.25^{*}$ & $0.28^{*}$ & $-0.31^{*}$ & $0.22^{*}$ & $-0.27^{*}$ \\
\hline Night Shifts & $-0.18^{*}$ & 0.03 & $0.24^{*}$ & $0.39^{*}$ & $-0.41^{*}$ & $0.33^{*}$ & $-0.38^{*}$ \\
\hline Days Off & -0.10 & 0.03 & $0.16^{*}$ & $0.20^{*}$ & $-0.29^{*}$ & 0.14 & $-0.23^{*}$ \\
\hline Sleep Apnea Scale & -0.12 & 0.08 & $0.24^{*}$ & $0.44^{*}$ & $-0.24^{*}$ & $0.39^{*}$ & $-0.25^{*}$ \\
\hline Epworth Sleepiness Scale & -0.03 & 0.08 & $0.22^{*}$ & $0.39^{*}$ & -0.06 & $0.32^{*}$ & $-0.17^{*}$ \\
\hline Physical Health: Digestive & -0.06 & 0.13 & $0.23^{*}$ & $0.41^{*}$ & $-0.23^{*}$ & $0.36^{*}$ & $-0.23^{*}$ \\
\hline Physical Health: Cardiovascular & $r \quad-0.14$ & 0.04 & $0.25^{*}$ & $0.37^{*}$ & $-0.24^{*}$ & $0.32^{*}$ & $-0.25^{*}$ \\
\hline General Mental Health & $-0.17^{*}$ & 0.01 & $0.34^{*}$ & $0.38^{*}$ & $-0.27^{*}$ & $0.33^{*}$ & $-0.26^{*}$ \\
\hline Cognitive Anxiety & $-0.18^{*}$ & 0.05 & $0.41^{*}$ & $0.40^{*}$ & $-0.21^{*}$ & $0.35^{*}$ & $-0.24^{*}$ \\
\hline Somatic Anxiety & -0.14 & 0.09 & $0.38^{*}$ & $0.41^{*}$ & $-0.23^{*}$ & $0.36^{*}$ & $-0.25^{*}$ \\
\hline Neuroticism & -0.13 & 0.10 & $0.39^{*}$ & $0.49^{*}$ & $-0.30^{*}$ & $0.44^{*}$ & $-0.30^{*}$ \\
\hline Minnesota Satisfaction & 0.08 & -0.01 & $-0.16^{*}$ & $-0.33^{*}$ & $0.23^{*}$ & $-0.31^{*}$ & 0.28 \\
\hline Alienation/Involvement & 0.10 & 0.02 & -0.11 & $-0.27^{*}$ & $0.28^{*}$ & $-0.25^{*}$ & $0.35^{*}$ \\
\hline
\end{tabular}

${ }^{*} \mathrm{p}<0.0001$ 
instrument may be successfully translated and used in other cultures, was followed and provided positive results.

The results of the exploratory factor analyses provided sufficient support regarding the dimensionality of the scales of the SSI as reported by Barton, Costa et al. (1995) to regard the scales as demonstrating a fair degree of construct validity for the present sample A confirmatory approach was considered premature, because the authors of the SSI indicated that more developmental work on the scales was required. This decision was vindicated by the fact that most of the obtained reliabilities for the various scales were moderate to satisfactory, but not as high as one may expect from carefully constructed scales. Furthermore, several questionable items in the scales were pointed out in these exploratory analyses and this information may now be used to improve the SSI scales.

The obtained reliability coefficients compared favourably with results obtained by Barton Costa et al. (1995) and others (Johns, 1992; Roodt, 1991; Weiss et al., 1967). With the exception of the two scales of the Eysenck Personality Inventory, it may be seen from Table 1 that the scales were generally fairly reliable (internally consistent) for train drivers. The low reliability of the Sleep Disturbance Scale-Morning Shifts (0.66) might be the result of a possible misunderstanding by some of the urban train drivers whose early shift starts at 04 h00. They might not have followed the questionnaire instructions which stipulated that a morning shift is one that starts after 06h00 A further explanation is that this scale has only five items compared with the six items of the original scale. The Coping Questionnaire subscales, having four items each compared with the original 16, also had lower reliabilities than those reported by Barton, Costa et al. (1995) for probably the same reason. It was a goal of Barton, Costa et al. (1997) to construct relatively short scales for use in research, but in the case of most of these scales the alpha coefficients and also the content validity of the scales might have improved had a larger number of relevant items been included.

The correlations between the scales also confirmed their construct validity and supported the theoretical model proposed by the developers of the SSI. The substantial correlations between the various sleep-related variables, and the various physical and mental health variables emphasised the high degree of interrelatedness between the physical and psychological health of the shiftworker.

The correlations between the moderator and outcome variables provided an even clearer picture of the relationships between these variables than those found during the development of the SSI (Barton, Costa et al., 1995). Inclusion of the sleepiness and sleep disorders questionnaires and the Minnesota Satisfaction and Job Alienation/lnvolvement scales appeared to supplement the outcome-based model proposed by Barton, Costa et al. (1997). The substantial correlations between the avoidance/ disengagement coping strategy, and several outcome variables, particularly the psychological health variables, indicating the negative effects of this coping strategy, was also replicated in a study by Pisarski (1997). It was found that the use of disengagement coping strategies by nurses on rotating shifts was associated with high levels of physical and psychological symptoms. It is argued that the correlations between the variables obtained in this study are not simply due to common method variance as might be the case in self-report measures, because the items were not all of the same type and several low correlations were also obtained. Furthermore, the authors of the

TABLE 3

COMPARISON OF SCALE MEANS WITH THOSE OBTAINED BY BARTON, COSTA ET AL. (1995)

\begin{tabular}{|c|c|c|c|c|c|c|c|c|}
\hline \multirow[b]{2}{*}{ Scale } & \multicolumn{3}{|c|}{ Train drivers } & \multicolumn{3}{|c|}{ Comparative study ${ }^{* * *}$} & \multirow[b]{2}{*}{$t$} & \multirow{2}{*}{$\begin{array}{l}\text { Effect } \\
\text { size } r\end{array}$} \\
\hline & $N$ & $M$ & $S D$ & $N$ & $M$ & $S D$ & & \\
\hline Social Disruption & 727 & 3.81 & 1.26 & 422 & 3.27 & 1.22 & $7.12^{*}$ & 0.21 \\
\hline Domestic Disruption & 726 & 3.41 & 1.27 & 422 & 2.80 & 1.16 & $8.15^{*}$ & 0.23 \\
\hline Nondomestic Disruption & 723 & 3.21 & 1.30 & 422 & 2.35 & 1.18 & $11.24^{*}$ & 0.32 \\
\hline \multicolumn{9}{|l|}{ Sleep disturbances before: } \\
\hline Morning Shifts ${ }^{* *}$ & 723 & 13.02 & 3.78 & 422 & 17.80 & 4.48 & $-19.39^{*}$ & 0.50 \\
\hline Afternoon Shifts ${ }^{* *}$ & 716 & 14.98 & 4.62 & 422 & 14.40 & 3.73 & 2.20 & 0.07 \\
\hline Night Shifts** & 716 & 16.82 & 5.24 & 422 & 18.44 & 4.87 & $-6.38^{*}$ & 0.19 \\
\hline Days Off* & 713 & 13.52 & 4.13 & 422 & 12.71 & 3.38 & $3.47^{*}$ & 0.10 \\
\hline Physical Health: Digestive & 724 & 14.23 & 5.07 & 422 & 13.88 & 4.76 & 1.16 & 0.03 \\
\hline Physical Health: Cardiovascular & 722 & 10.16 & 2.96 & 422 & 10.28 & 2.80 & -0.68 & 0.02 \\
\hline General Mental Health & 718 & 10.94 & 5.89 & 422 & 11.38 & 4.80 & -1.31 & 0.04 \\
\hline Cognitive Anxiety & 720 & 12.56 & 5.66 & 422 & 12.21 & 5.37 & 1.04 & 0.03 \\
\hline Somatic Anxiety & 720 & 14.04 & 5.29 & 422 & 13.13 & 4.80 & $2.93^{*}$ & 0.09 \\
\hline Coping: Engagement ${ }^{* *}$ & 700 & 50.32 & 15.16 & 422 & 42.35 & 10.74 & $9.57^{*}$ & 0.27 \\
\hline Coping: Disengagement ${ }^{* *}$ & 695 & 38.56 & 15.44 & 422 & 29.68 & 10.53 & $11.78^{*}$ & 0.33 \\
\hline \multicolumn{9}{|l|}{ Circadian type: } \\
\hline Languidness/Vigorous - Final & 723 & 25.80 & 6.67 & 422 & 31.00 & 6.35 & $-13.04^{*}$ & 0.34 \\
\hline Flexibility/Rigidity - Final & 723 & 27.10 & 5.42 & 422 & 26.10 & 5.21 & $3.08^{*}$ & 0.09 \\
\hline Neuroticism & 720 & 11.24 & 3.19 & 422 & 12.03 & 3.18 & $-4.08^{*}$ & 0.12 \\
\hline Extraversion & 721 & 15.62 & 3.33 & 422 & 17.09 & 3.20 & $-7.36^{*}$ & 0.21 \\
\hline
\end{tabular}

${ }^{*} p<0.01$

** The means and SDs obtained by the train drivers were adjusted proportionately to match the same number of items as the SSI.

*** Statistics obtained for 422 male participants during the development of the SSI by Barton, Costa et al. (1995). 
TABLE 4

COMPARISON OF SCALE MEANS WITH LOCAL AND INTERNATIONAL RESULTS

\begin{tabular}{|c|c|c|c|c|c|c|c|c|}
\hline \multirow[b]{2}{*}{ Scale } & \multicolumn{3}{|c|}{ Train drivers } & \multicolumn{3}{|c|}{ Comparative study ${ }^{* * *}$} & \multirow[b]{2}{*}{$t$} & \multirow{2}{*}{$\begin{array}{l}\text { Effect } \\
\text { size } r\end{array}$} \\
\hline & $N$ & $M$ & $S D$ & $N$ & $M$ & $S D$ & & \\
\hline Social Disruption & 727 & 3.81 & 1.26 & 347 & $3.28^{10}$ & $1.18^{*}$ & $6.55^{* *}$ & 0.20 \\
\hline Domestic Disruption & 726 & 3.41 & 1.27 & 347 & $2.66^{10}$ & $1.16^{*}$ & $9.26^{* *}$ & 0.27 \\
\hline Nondomestic Disruption & 723 & 3.21 & 1.30 & 347 & $2.49^{10}$ & $1.19^{*}$ & $8.67^{* *}$ & 0.26 \\
\hline \multicolumn{9}{|l|}{ Sleep disturbances before: } \\
\hline \multirow[t]{2}{*}{ Morning Shifts ${ }^{* * *}$} & 723 & 13.02 & 3.78 & 361 & $18.37^{9}$ & $4.10^{*}$ & $-21.25^{* *}$ & 0.54 \\
\hline & & & & 77 & $18.14^{11}$ & $4.10^{*}$ & $-11.18^{* *}$ & 0.37 \\
\hline \multirow[t]{2}{*}{ Afternoon Shifts ${ }^{* * *}$} & 716 & 14.98 & 4.62 & 361 & $15.57^{9}$ & $3.62^{*}$ & -2.10 & 0.06 \\
\hline & & & & 77 & $13.86^{11}$ & $3.62^{*}$ & 2.05 & 0.07 \\
\hline \multirow[t]{3}{*}{ Night Shifts ${ }^{* * *}$} & 716 & 16.82 & 5.24 & 138 & $16.30^{8}$ & $5.05^{*}$ & 1.09 & 0.04 \\
\hline & & & & 361 & $20.82^{9}$ & $5.05^{*}$ & $-11.87^{* *}$ & 0.34 \\
\hline & & & & 77 & $17.54^{11}$ & $5.05^{*}$ & -1.15 & 0.04 \\
\hline \multirow[t]{3}{*}{ Days Off ${ }^{* * *}$} & 713 & 13.52 & 4.13 & 138 & $14.82^{8}$ & $3.57^{*}$ & $-3.46^{* *}$ & 0.12 \\
\hline & & & & 361 & $12.51^{9}$ & $3.57^{*}$ & $3.99^{* *}$ & 0.12 \\
\hline & & & & 77 & $12.51^{11}$ & $3.57^{*}$ & 2.09 & 0.07 \\
\hline \multirow[t]{7}{*}{ Epworth Sleepiness Scale } & 722 & 7.54 & 3.89 & 30 & $5.9^{1}$ & 2.2 & 2.29 & 0.08 \\
\hline & & & & 32 & $6.5^{2}$ & 3.0 & 1.49 & 0.05 \\
\hline & & & & 55 & $11.7^{3}$ & 4.6 & $-7.53^{* *}$ & 0.26 \\
\hline & & & & 13 & $17.5^{4}$ & 3.5 & $-9.16^{* *}$ & 0.32 \\
\hline & & & & 14 & $17.9^{5}$ & 3.1 & $-9.90^{* *}$ & 0.34 \\
\hline & & & & 18 & $2.2^{6}$ & 2.0 & $5.80^{* *}$ & 0.21 \\
\hline & & & & 18 & $9.2^{7}$ & 4.0 & -1.79 & 0.07 \\
\hline \multirow[t]{2}{*}{ Physical Health: Digestive } & 724 & 14.23 & 5.07 & 138 & $13.15^{8}$ & $4.55^{*}$ & 1.75 & 0.06 \\
\hline & & & & 361 & $14.68^{9}$ & $4.55^{*}$ & -1.42 & 0.04 \\
\hline \multirow[t]{2}{*}{ Physical Health: Cardiovascular } & 722 & 10.16 & 2.96 & 138 & $10.04^{8}$ & $2.69^{*}$ & 0.44 & 0.004 \\
\hline & & & & 361 & $10.33^{9}$ & $2.69^{*}$ & -0.91 & 0.03 \\
\hline \multirow[t]{2}{*}{ General Mental Health } & 718 & 10.94 & 5.89 & 138 & $10.72^{8}$ & $5.22^{*}$ & 0.41 & 0.01 \\
\hline & & & & 361 & $13.38^{9}$ & $5.22^{*}$ & $-6.63^{*}$ & 0.20 \\
\hline \multirow[t]{2}{*}{ Cognitive Anxiety } & 720 & 12.56 & 5.66 & 138 & $11.24^{8}$ & $5.24^{*}$ & 2.54 & 0.09 \\
\hline & & & & 361 & $12.78^{9}$ & $5.24^{*}$ & -0.61 & 0.02 \\
\hline \multirow[t]{2}{*}{ Somatic Anxiety } & 720 & 14.04 & 5.29 & 138 & $11.99^{8}$ & $4.45^{*}$ & $4.28^{* *}$ & 0.14 \\
\hline & & & & 361 & $13.63^{9}$ & $4.45^{*}$ & 1.26 & 0.04 \\
\hline Coping: Engagement ${ }^{* * *}$ & 700 & 50.32 & 15.16 & 75 & $49.48^{14}$ & 17.72 & 0.45 & 0.02 \\
\hline Coping: Disengagement ${ }^{* * *}$ & 695 & 38.56 & 15.44 & 75 & $36.20^{14}$ & 14.40 & 1.27 & 0.05 \\
\hline \multirow[t]{2}{*}{ Neuroticism } & 720 & 11.24 & 3.19 & 138 & $11.99^{8}$ & $3.13^{*}$ & -2.54 & 0.09 \\
\hline & & & & 361 & $13.46^{9}$ & $3.13^{*}$ & $-10.81^{* *}$ & 0.31 \\
\hline Minnesota Satisfaction & 722 & 66.16 & 11.54 & 1723 & $74.85^{13}$ & 11.92 & $-16.53^{* *}$ & 0.32 \\
\hline Alienation/Involvement & 718 & 52.89 & 9.24 & 870 & $52.52^{12}$ & 8.25 & 0.85 & 0.02 \\
\hline
\end{tabular}

* In some instances the $S D$ s of the scales used in the comparative studies were not available. For the $t$ tests the $S D s$ obtained for 1864 shiftworkers by Barton, Costa et al. (1995) were then used as 'best estimate'.

** $p<0.01$

*** The means and SDs obtained by the train drivers were adjusted proportionately to match the same number of items as the SSI.

1 Mean for control group of hospital employees with normal sleep habits without snoring

2 Mean for participants suffering from primary snoring (Johns, 1991)

3 Mean for participants suffering from obstructive sleep apnea syndrome (Johns, 1991)

4 Mean for participants suffering from narcolepsy (Johns, 1991)

5 Mean for participants suffering from idiopathic hypersomnia (Johns, 1991)

6 Mean for participants suffering from insomnia (Johns, 1991)

7 Mean for participants suffering from periodic limb movement disorder (Johns, 1991)

8 Mean for permanent night shift nurses on a regular fixed roster (Barton et al., 1993)

9 Mean for rotating shift nurses on an irregular roster (Barton et al., 1993)

10 Mean for rotating shift nurses (Barton, 1994)

11 Mean for serving transport police officers (Spelten et al., 1993)

12 Mean for 870 South African business school graduates (Roodt, 1991)

13 Mean for 1723 varied employees (Weiss et al., 1967)

14 Mean for 75 South African shiftworkers in the rubber industry (Potgieter, 1996) 
SSI have subsequently validated a process model based on the theoretical model that they proposed during the development of the SSI (Smith et al., 1997). The validation of moderatoroutcome models by means of cross-sectional studies should however be approached with caution, because the results are often not replicated in longitudinal studies (Kaliterna et al., 1995).

The General Job Satisfaction, Chronic Fatigue, and Composite Morningness Questionnaires were omitted in the present study. The content validity of the job satisfaction and fatigue scales were regarded as suspect, because the items in each of these short scales are too similar to claim proper content sampling of the domains of job satisfaction and fatigue respectively. The job satisfaction scale was replaced by the Minnesota Satisfaction Questionnaire and the Job Alienation/Involvement Questionnaire. Factor analyses of these scales were not reported here, but inspection of their internal consistencies and correlations with other SSI scales suggests that either or both of these questionnaires may fruitfully be added to the SSI.

The scope of the SSI in this study was further enhanced by the addition of the Epworth Sleepiness and the Sleep Apnea scales to assess the extent to which train drivers suffer from symptoms of sleep disorders and daytime sleepiness. Although the actual presence of sleep disorders is best assessed in the laboratory, the construct validity of the rest of these subjective self-report measures may be compromised in the same sense. Furthermore, the relevance of the sleep questionnaires was clear from their substantial correlations with languidness, as well as with the various mental and physical health variables. The possible presence of sleepiness on the job and sleep disorders in shiftworkers must surely rate among the most serious consequences of shiftwork in jobs where accidents may occur. Inclusion of such questionnaires in the SSI appear justified, particularly in view of previous research indicating the incidence of sleep deprivation, sleepiness, and sleep disorders in relation to shiftwork (Bohle, 1997, Kecklund et al., 1997; Torsvall et al., 1987).

The primary purpose of comparing the various scale means with results obtained in other studies, was not to compare the effects of different shift systems, but to establish whether the SSI would produce credible results if translated for another cultural group. The comparisons provided mixed positive, negative, and insignificant results, indicating that deviations in one direction only, were not found. Nevertheless, compared with British male shiftworkers of whom about 80 percent were estimated to work regular shifts, the train drivers experienced more disruption of their private lives, but fewer sleep disturbances (Barton, Costa et al., 1995). The result regarding disruption of the train driver's private lives was replicated when they were compared with rotating shift nurses (Barton, 1994). Few significant differences were found between the train drivers and British night shift nurses on a regular roster (Barton et al., 1993), but the train drivers obtained more positive results than rotating shift nurses on an irregular roster (Barton et al., 1993). In interpreting the latter results, it should be borne in mind that the male train driver sample was being compared with a predominantly female sample. It has been shown that the psychological effects of shiftwork influence females more negatively than males (Barton, Costa et al.,1995). Therefore. no clear-cut choice between regular and irregular shifts based on these data was possible.

The results of the present study provide support for the validity of the SSI across cultures and languages. The evidence provided here confirms that the SSI may be used as a standard instrument to establish which types of shift systems are least detrimental for shiftworkers, which aspects of shiftworkers' lives are most affected by shiftwork. and to identify the personality attributes and coping strategies associated with individuals who are most likely to tolerate the disruption resulting from shiftwork. In short. the SSI may be regarded as a valuable research tool. It should however be kept in mind that the psychometric properties of the various scales are not strong enough for individual diagnosis and that they should not be used for assessing individual shiftworkers. Further refinement of the SSI scales might therefore be useful.

\section{REFERENCES}

Adler, T. (1991). Sleep for sale: A study of shiftwork in South Africa. Johannesburg: Witwatersrand University Press.

Aguirre, A., Heitmann, A., Trutschel, U., Fordham, P., Mathews, K., Khuri, R., Gerber P. \& Moore-Ede, M. (1997). Sleep apnea as a risk factor in railroad operations. Paper presented at the Xlll International Symposium on Night and Shiftwork, June, Majvik, Finland.

Barton, J. (1994). Choosing to work at night: A moderating influence on individual tolerance to shiftwork. Journal of Applied Psychology, 79, 449-454.

Barton, J., Costa, G., Smith, L., Spelten, E., Totterdell, P. \& Folkard, S. (1995). The Standard Shiftwork Index: A battery of questionnaires for assessing shiftwork related problems. Work and Stress, 9, 4-30.

Bohle, P.L. (1997). Sleep and circadian rhythm characteristics as predictors of adjustment to shiftwork. International Journal of Occupational and Environmental Health 3(3), 30-34.

Brophy, P.R. (1993). shiftwork and family structure: An ecosystemic approach. Unpublished master's thesis, University of South Africa, Pretoria.

Buysse, D.J. (1991). Drugs affecting sleep, sleepiness and performance. In T.H. Monk (Ed.), Sleep, sleepiness and performance (pp. 249-306). Chichester: Wiley.

Cook, J D, Hepworth, S.J., Wall, T.D. \& Warr, P.B. (1981). The experience of work. London: Academic Press.

Dumont. M., Montplaisir, J. \& Infante-Rivard, C. (1997). Sleep quality of former night-shiftworkers. International Journal of Occupational and Environmental Health 3(3), 10-14.

Folkard, S. \& Barton, J. (1993). Does the 'forbidden zone' for sleep onset influence morning shift sleep duration? Ergonomics, 36, 85-91.

Gallo, L C \& Eastman, C.l. (1993). Circadian rhythms during gradually delaying and advancing sleep and light schedules. Physiology and Behavior, 53, 119-126.

Goldman, S. (1992). The wellbeing sequelae of shiftwork in a group of South African workers. Unpublished master's thesis, University of the Witwatersrand, Johannesburg.

Hänecke, K., Tiedeman, S., Nachreiner, F. \& Grzech-Šukalo, H. (1997). Accident risk as a function of time on task and time of day. Paper presented at the XIII International Symposium on Night and Shiftwork, June, Majvik, Finland.

Härmä, M. Kervinen, V., Sallinen, M., Lundelin, T. \& Toppila, M. Health counseling on individual coping strategies to reduce sleepiness in shiftwork. Proceedings of the 13th Triennal Congress of the International Ergonomics Association, Volume 1, Tampere, Finland, 544-546.

Heslegrave, R.J. \& Rhodes, W. (1997). Prevalence of health complaints in air traffic controllers working shiftwork. Paper presented at the XIII International Symposium on Night and Shiftwork, June, Majvik, Finland.

Hildebrandt, G., Rohmert, W. \& Rutenfranz, J. (1974). Twelve and 24 hour rhythms in error frequency of locomotive drivers and the influence of tiredness. International Journal of Chronobiology, 2, 175-180.

Iskra-Golec, I. (1993). The relationship between circadian, personality, and temperament characteristics and attitude towards shiftwork. Ergonomics, 36, 149-153

Johns, M.W. (1991). A new method for measuring daytime sleepiness: The Epworth Sleepiness Scale. Sleep, 14, 540-545.

Johns, M.W. (1992). Reliability and factor analysis of the Epworth Sleepiness Scale. Sleep. 15, 376-381.

Johns, M.W. (1994). Sleepiness in different situations measured by the Epworth sleepiness Scale. Sleep, 17, 703-710.

Kaliterna, L., Vidacek, S., Prizmic, Z. \& Radosevic-Vidacek, B. 
(1995). Is tolerance to shiftwork predictable from individual difference measures? Work and Stress, 9, 140-147.

Kaliterna, L., Vidacek, S., Radosevic-Vidacek, B. \& Prizmic, Z. (1993). The reliability and stability of various individual difference and tolerance to shiftwork measures. Ergonomics, 36, 183-189.

Kecklund, G., Äkerstedt, T., Gillberg, M. \& Lowden, A. (1997). Task, Shift and sleepiness: A meta-analysis. Paper presented at the Xlll International Symposium on Night and Shiftwork, June, Majvik, Finland.

Klein, M (1995). The shift worker's handbook: A personal health and lifestyle guide for shift work professionals. Lincoln: SynchroTech.

Knutsson, A., Hallqvist, J., Reuterwall, C. \& Theorell, T. (1997). Shiftwork and job strain as risk factors for myocardial infarction in the SHEEP study. Paper presented at the Xlll lnternational Symposium on Night and Shiftwork, June, Majvlk Finland.

Lauber, J.K. \& Kayten, P.J. (1988). Sleepiness, circadian dysrhythmia and fatigue in transportation system accidents. Sleep, 11, 503-512.

Lefkowltz, J., Somers, M.J. \& Weinberg, K. (1984). The role of need level and/or need salience as moderators of the relationship between need satisfaction and work alienationinvolvement. Journal of Vocational Behavior, 24, 142-158.

Monk, T.H. (1990). The relationship of chronobiology to sleep schedules and performance demands. Work and Stress, 4, 227-236.

Monk, T.H. \& Folkard, S. (1992). Making shiftwork tolerable. London: Taylor \& Francis.

Murrel, K.F.H. (1965). Ergonomics: Man in his working environment. London: Chapman-Hall.

Pieterse, F.L.J.B. (1997). Die invloed van werknemerbemagtiging op skofwerkers se doeltreffendheid en hul persepsies van die gehalte van hul werklewe (The influence of employee empowerment on the efficiency of shiftworkers and their perceptions of the quality of their work life). Unpublished master's thesis, University of South Africa, Pretoria.

Pisarski, A. (1997). Work/non-work conflict and shiftworkers health: Main and moderating effects of relationship status, support, and coping. Paper presented at the XIll International Symposium on Night and Shiftwork, June, Majvik, Finland.

Potgieter, T.E. (1996). Hardiness and tenure in shiftwork as predictive variables for coping with shiftwork. Unpublished master's thesis, University of South Africa, Pretoria.

Presser, H.B. (1997). The relationship between shiftwork and marital status in the U.S.: A longitudinal view. Paper presented at the Xlll International Symposium on Night and Shiftwork, June, Majvik, Finland.

Prunier, S. Gadbois, C. \& Foret, J. (1997). Unfavorable consequences of six-hour shiftwork. International Journal of Occupational and Environmental Health, 3(3), 53-60

Roodt, G. (1991). Die graad van werkbetrokkenheid as voorspeller van persoonlike welsyn ' $n$ Studie by bestuurders (The degree of work involvement as predictor of personal well-being: a
Study of managers). Unpublished doctoral dissertation, University of the Orange Free State, Bloemfontein.

Rosenthal, R. \& Rosnow, R. (1991). Essentials of behavioral research: Methods and data analysis. New York: McGraw-Hill, 1991.

Scott, A.J. Monk, T.H. \& Brink, L.L. (1997). Shiftwork as a risk factor for depression: A pilot study. International Journal of Occupational and Environmental Health, 3(3), 2-9.

Sharmin, S. \& Rahman, A. (1997). Mental health, occupational stress, job satisfaction and life satisfaction of hospital doctors by job nature and work schedule. Paper presented at the XIII International Symposium on Night and Shiftwork, June, Majvik, Finland.

Shaw, O.B. (1980). Die rol van menslike faktore by sinjaal-opgevaar-verby insidente in die Suid-Afrikaanse Spoorwee (The role of human factors in signal-passed-at-danger incidents in the South African Railways). Unpublished master's thesis University of South Africa, Pretoria.

Smith, C., Robie, C., Folkard, S., Barton, J., Macdonald, I., Smith, L., Spelten, E., Totterdell, P. \& Costa, G. (1997). Validation of a process model of shiftwork and health. Paper presented at the XIIl International Symposium on Night and Shiftwork, June, Majvik, Finland.

Smith, P.A., Brown, D.F., Di Milia, L. \& Wragg, C. (1993). The use of the Circadian Type Inventory as a measure of the circadian constructs of vigour and rigidity. Ergonomics, 36, 169-175.

Spelten, E., Barton, J. \& Folkard, S. (1993). Have we underestimated shiftworkers' problems? Evidence from a 'reminiscence' study. Ergonomics, 36, 307-312.

Taylor, E, Folkard, S. \& Shapiro, D.A. (1997). Shiftwork advantages as predictors of health. International Journal of Occupational and Environmental Health, 3(3), 20-29.

Tenkamen, L., Sjöblom, T., Kalimo, R., Alikoski, T. \& Härmä, M. (1997). Shift work, occupation and heart disease: Experience from the Helsinki Heart Study. Paper presented at the XIII International Symposium on Night and Shiftwork, June, Majvik, Finland.

Torsvall, L., Ảkerstedt, T. \& Gillberg, M. (1987). Sleepiness on the job: Continuously measured EEG changes in train drivers. Clinical Neurophysiology, 66, 502-511.

Tucker, P., Smith, L., Macdonald, l. \& Folkard, S. (1997). The impact of early and late shift changeovers upon sleep, health and well-being. Paper presented at the XIll International Symposium on Night and Shiftwork, June, Majvik, Finland.

Visser, D. (1996). The development of a scale to measure symptoms of sleep apnea in shiftworkers. Paper presented at the Fifth International Conference on Work Values and Behaviour, International Society for the Study of Work and Organizational Values, Montreal, Canada.

Weiss, D.J., Dawis, R.V., England, G.W. \& Lofquist, L.H. (1967). Manual for the Minnesota Questionnaire. Industrial Relations Center, University of Minnesota. 